\title{
Los estudios hispanos sobre el África subsahariana: una perspectiva histórica
}

\author{
GERMÁN SANTANA PÉREZ y MARIVÍ ORDÓÑEZ DEL PINO* \\ Universidad de Las Palmas de Gran Canaria \\ y Universidad Autonoma de Madrid
}

\section{The Spanish studies about Subsaharian Africa: A historical perspective}

\begin{abstract}
RESUMEN
La escasa importancia del colonialismo español en África explica en parte por qué

los estudios hispanos sobre el África subsahariana han sido casi desconocidos.

Sin embargo, éstos gozan de una larga trayectoria e incluso han sido pioneros en algunos casos durante el pasado. En este artículo hemos pretendido dar una visión general de estos estudios hispanos desde

la Antigüedad hasta la actualidad. La

información que procedía de África se

incrementó en los inicios de la Edad

Moderna debido a la época de los

descubrimientos. Durante el periodo

colonial el mayor interés de estos trabajos

se centró en la colonia española de

Guinea Ecuatorial. Después del periodo

de la dictadura de Franco se gestó una

nueva orientación, en la que imperó un

ambiente de mayor libertad y unas

mayores conexiones con el africanismo

internacional. El objetivo de este artículo

es analizar las tendencias más

importantes dentro del africanismo

español, señalando los representantes
\end{abstract}

\begin{abstract}
The little importance of the Spanish colonialism in Africa explains why the Spanish studies about Subsaharian Africa are almost unknown. However, they have a long tradition and they have been leaders on this subject in the past. We have sought to give a general vision of the Spanish studies from the Antiquity to the present day. The information that came from Africa increased at the beginning of the Early Modern History due to the rise of the discoveries. During the colonial period most of the interest was focused on Equatorial Guinea. After Francos's dictatorship these studies were given a fresh orientation with more freedom and a greater international connection. The objective of this article is to analyze the most important tendencies in the Spanish Africanism, with its most distinguished figures. However, we do not wish to make an exhaustive list including all its representatives figures.
\end{abstract}

* ULPGC, Depto. Ciencias Históricas. C/ Pérez del Toro, s/n. 35003 - Las Palmas de Gran Canaria. gsantana@dch.ulpgc.es. UAM, Grupo de Estudios Africanos, Dpto. Ciencia Política y Relaciones Internacionales. C/ Marie Curie, 1. 28049 - Cantoblanco (Madrid). marivi.ordonnez@uam.es. 
más destacados. No pretende, en ningún caso, convertirse en la elaboración de una lista exhaustiva, con todas las figuras de este africanismo.
KEYWORDS:

Africa / Spain / Africanism / History /

Historiography / tendencies / evolution.

PALABRAS CLAVE:

África / España / africanismo / historia / historiografía / tendencias / evolución.

Las imágenes sobre la relación de España y el África subsahariana ${ }^{1}$ en la actualidad están teñidas, de una parte, por los recientes acontecimientos relacionados con la inmigración y, de otra, por el todavía cercano pasado colonial en Guinea Ecuatorial, en el que la contribución española al conocimiento ha sido demasiado modesta. Por ello hemos considerado necesario rescatar a muchos de los autores hispanos que durante siglos se han acercado a la realidad africana con muy diferentes motivaciones y propósitos, con el fin de comprender unas relaciones históricas mucho más complejas y diversas de lo que estamos acostumbrados a pensar. No se trata de un catálogo exhaustivo de investigadores y obras sino más bien de un primer bosquejo que nos permita ir avanzando en el conocimiento de las relaciones hispano-africanas y de las tendencias que condicionaron estos estudios en cada época.

La posición estratégica de la Península como llave del Mediterráneo, además de frontera con África y, en muchas ocasiones, final de camino de rutas, hizo que jugara un papel clave en la recepción de información procedente de este continente. Pero históricamente se ha puesto un mayor énfasis en el número de trabajos que tienen por objeto el estudio del Norte de África, en comparación con los que se han decantado por el África subsahariana.

\section{LAS FUENTES ANTIGUAS Y EL SABER ENCICLOPÉDICO}

África nunca ha estado aislada. Pero resulta difícil establecer cuáles fueron los contactos reales que pudieron tener las sociedades mediterráneas de la Antigüedad con el interior africano. La comunicación más fluida se produjo a través de Egipto y del Mar Rojo, mientras apenas puede hablarse de contactos con la zona occidental, siempre hubo filtraciones a través del Sáhara. Las fuentes escritas atestiguan que existían conocimientos, casi siempre por medio de fuentes secundarias como viajeros y comerciantes, dando como resultado un panorama general extravagante y atemporal. $Y$ el arte permite confirmar que hubo africanos subsaharianos en la zona mediterránea y que su presencia no fue más extraña que la de

${ }_{1}^{1}$ A partir de ahora y durante todo nuestro artículo hablaremos de África refiriéndonos exclusivamente al África subsahariana. 
otros pueblos del norte de Europa. Sin embargo, los pocos autores como Ptolomeo o Cosmas Indocopleustes que aportaron datos más precisos tuvieron una escasa difusión en la Edad Media europea².

La Península Ibérica, en el extremo del imperio romano, apenas puede considerarse representativa del mundo antiguo en cuanto a conocimiento geográfico africano, si bien es cierto que la circulación de obras y cultura, primero griega y luego latina, sí tuvo lugar. Hasta la llegada de africanos negros a través de Al-Andalus a partir del siglo VIII d. C., no puede constatarse ningún contacto directo con subsaharianos y mucho menos autores que puedan ofrecer datos de primera mano. La falta de relaciones fehacientes con África explica que no se desarrollara ningún tipo de política activa. La razón de la aparición de esta zona geográfica en las obras de los primeros siglos de nuestra era responde, por tanto, a otros intereses de carácter representativo y simbólico. El ser humano necesita definirse y definir su mundo. De ahí que la zona subsahariana no haya sido nunca ajena a descripciones.

El único representante reseñable en nuestro suelo es Pomponio Mela. Su Corografía se sitúa en torno al año 40 d. C. y la información que aporta sobre África procede en su totalidad de obras precedentes. Su principal fuente etnográfica fue Heródoto, aunque no de forma directa, sino a través de intermediarios como Varrón, Estrabón o Virgilio. Mela tuvo amplia influencia en autores posteriores como Solino o Marciano Capella, que, a su vez, sirvieron de punto de partida a muchos escritores medievales incluidos los hispanos ${ }^{3}$.

Haciéndose eco del saber antiguo, Mela situó África como una de las tres masas continentales dentro de la cual estaría la región de Etiopía ${ }^{4}$, habitada por los etíopes, así bautizados por los griegos en alusión al color de su piel: aethiops, 'cara quemada'. Pomponio anuncia ya las características geográficas que serán repetidas, sin datos contrastables, durante siglos y que imprimirán sobre la imagen africana una simbología de extremo: lugar agreste, sequedad de sus tierras... La relación entre el clima excesivamente caluroso de la zona etíope y las características físicas de sus pobladores será una constante. Y los climas extremos sólo podían dar como resultado humanidades extremas.

\section{EL CRISTIANISMO}

El contacto real con África subsahariana en los siglos altomedievales continuó siendo inexistente y los autores que versaron sobre el tema en esta etapa sólo pu-

\footnotetext{
2 MEDEIROS, François de: L'Occident et l'Afrique (XIIle-XVe siècle). Images et représentations, Karthala, Centre de Recherches Africaines, París, 1985, p. 41.

${ }^{3}$ MELA, Pomponio: Corografía [traducción y notas a cargo de C. Guzmán Arias, Universidad de Murcia, Murcia, 1989], pp. 23-24.

${ }_{4}$ África era dividida por lo general en tres partes: Libia (el norte de Africa), Egipto y Etiopía. Ésta última abarcaba, por tanto, toda la zona desconocida al sur del Sáhara.
} 
dieron basar su conocimiento en obras precedentes. Sin embargo, es fundamental entender que este hecho no resta valor a las obras, antes bien, constituyen unas fuentes de primer orden para comprender la transformación del pensamiento respecto a zonas geográficas como la africana, porque los primeros hispanos que toman contacto con África en la Modernidad lo harán con el deformado bagaje cultural de los siglos que ahora nos ocupan.

La desintegración política del imperio romano en los siglos IV-V, la ruralización provocada en parte por la inseguridad ante los recién llegados pueblos germanos y la decadencia de la vida urbana, llevaron consigo un repliegue paulatino de las formaciones políticas peninsulares hacia el interior y a un abandono durante varios siglos del pensamiento universalista, presente en buena parte del mundo mediterráneo desde el helenismo. A la llegada de los visigodos, la cultura latina se encontraba en manos de los hispanorromanos, estando el saber letrado casi exclusivamente en los poderes religiosos en torno a obispados y monasterios. La transmisión del saber y de los discursos se llevó a cabo por medio de síntesis y manuales que hacían más transmitible el mensaje, pero su reduccionismo fue al mismo tiempo abriendo distancia entre las imágenes de Europa y África ${ }^{5}$.

La llegada del cristianismo supuso en muchos casos una reapropiación y resignificación de la Antigüedad. El principal representante de esta postura ecléctica fue Isidoro de Sevilla, en el cual encontramos a un mismo tiempo una transmisión casi literal de autores greco-romanos junto a un nuevo discurso cristiano del mundo y la humanidad como la propia África. La magna obra de este obispo hispalense, las Etimologías, está salpicada de datos dispares sobre la geografía y población africanas, no siempre concordantes ni coherentemente trazados. En el proceso de cristianización del lenguaje y los discursos, Isidoro intercaló, junto a las fuentes antiguas, explicaciones derivadas del relato bíblico. Así, la diversidad humana se apoya ahora en un pasaje del Génesis, en el que los tres hijos de Noé -Sem, Cam y Jafet- serán los pobladores de los tres continentes conocidos: Asia, África y Europa respectivamente ${ }^{6}$.

Asimismo, las citas que encontramos sobre la zona subsahariana están llenas de vaguedades e imprecisiones. Etiopía sigue conservando sus características de tierra remota e inaccesible, llena de misterios y maravillas. Sin embargo, la obra de Isidoro de Sevilla constituye una de las fuentes principales de la que beberán los autores cristianos europeos posteriores hasta el contacto con las sociedades islamizadas. Su información será repetida hasta la saciedad y las pequeñas aportaciones irán más de la mano de la figuración y la tergiversación que de la noticia veraz.

Dos siglos más tarde, otro autor cristiano, Beato de Liébana, incluyó en su obra Comentario al Apocalipsis alusiones a Etiopía. Pero en este caso ya no se tra-

\footnotetext{
5 DEVISSE, J. (dir.): L'image du noir dans l'art occidental, Gallimard, Friburgo, 1979, vol. II, t.1, p. 51.

6 ISIDORO, San, Arzobispo de Sevilla: Etimologías [edición y traducción de J. Oroz Reta y M. Casquero. BAC, Madrid, 1982] IX, 2, pp. 10-13.
} 
ta de una obra enciclopédica como las que venimos aludiendo. Nos encontramos ante un nuevo género de literatura que pretende, a un mismo tiempo, la exégesis bíblica y la predicación. Pese a las circunstancias políticas y religiosas que motivaron la obra homilítica de Beato (la llegada de los musulmanes), las fuentes utilizadas no están basadas en su vivencia personal del momento histórico sino en fuentes anteriores, principalmente en los Padres de la Iglesia ${ }^{7}$. Si bien, la mención de la zona subsahariana carece de valor geográfico o etnográfico, adquiere una simbología nueva que dejará su huella palpable en los siglos posteriores: el pecado es comparado con la negrura y el oscurecimiento del alma. Y los etíopes son simbolizados como la negra gentilidad que debe encaminarse hacia la luz de la salvación ${ }^{8}$.

\section{LOS REINOS ANDALUSÍES Y LA REACCIÓN CRISTIANA (SIGLOS X-XII)}

Con la llegada de los musulmanes a la Península lbérica vamos encontrando cada vez con más frecuencia noticias que nos hablan de africanos subsaharianos en nuestro suelo, sobre todo en la región andalusí dominada por el Islam. A pesar de la dureza de su tránsito, el Sáhara nunca impidió la relación entre ambas orillas de sus arenas y las rutas transaharianas permitieron cierto contacto entre las poblaciones negras y los norteafricanos. Sobre la presencia africana en Al-Andalus, Dikr bilad al-Andalus (s. X) ya nombra la entrada de 700 negros junto a Tariq en el $711^{\circ}$ y el gran historiador Ibn Hayyan (s. X) en su Muqtabis cita también a esclavos negros en el ejército de la corte califal ${ }^{10}$. No son éstas ni mucho menos las únicas fuentes que atestiguan dicha presencia en suelo hispano pero no es éste el momento de detenernos en ellas.

La llegada, en el siglo XI, de los almorávides y, en el siglo XII, de los almohades supuso un incremento generoso de población subsahariana, llegada la mayoría formando parte de sus filas en los ejércitos o como esclavos al servicio de los jefes militares. No obstante, el conocimiento africano en Al-Andalus no se limitó a la experiencia cotidiana de sus gentes. Paulatinamente, las fuentes hispano-musulmanas demuestran que la comunidad islámica iniciaba un acercamiento a las regiones más allá del Sáhara como a otras zonas circundantes de sus

7 Comentario al Apocalipsis de Apringio de Beja [introducción, texto latino y traducción a cargo de A. del Campo Hernández, Verbo Divino, Estella, 1991], p. 57.

${ }_{8}$ Beato de Liébana no será el primero en hacer esta comparación. Algunos Padres de la Iglesia ya habían iniciado este camino anteriormente, especialmente Orígenes. Sobre la caracterización del color negro con aspectos peyorativos y sobre la simbología cristiana de Etiopía, véase COURTÉS, Jean Marie: «Traitement patristique de la thématique 'éthiopienne'», en J. DEVISSE (dir.), L'image du noir..., vol. II, t.1, pp. 9-31.

9 Una descripción anónima de Al-Andalus: Dikr bilad al-Andalus [traducción por Luis Molina, Instituto «Miguel Asín», CSIC, Madrid, 1983], t. 2, p. 106.

${ }_{10}$ RAZI, 'Isa ibn Ahmad al-: Anales palatinos del califa de Córdoba al-Hakam II. (El Califato de Córdoba en el Muqtabis de Ibn Hayyan) [traducción de E. García Gómez, Sociedad de Estudios y Publicaciones, Madrid, 1967], p. 237. 
territorios. El hecho más significativo es el inicio de noticias históricas, no siempre contemporáneas, que empiezan a dotar a los africanos de historicidad y, por tanto, de realidad. Dikr bilad al-Andalus nombra la revuelta de los Zany ${ }^{11}$ en Iraq en el año $890^{12}$. Las crónicas árabes nos hablan de Sudán (literalmente, as-Sudan es la «tierra de los negros»), nombre dado genéricamente a toda el África occidental y central subsahariana. Otra fuente nombra el reino de Gana y la islamización de sus gentes ${ }^{13}$.

Pero el advenimiento del Islam supuso sobre todo un punto de inflexión por su vocación de expansión política, comercial y religiosa, que incrementó notoriamente el tráfico caravanero con la zona subsahariana, así como el intercambio humano y cultural, dando lugar a nuevas oportunidades y necesidades de conocimiento mutuo. La gran contribución sobre África por parte del mundo islámico llegó desde los primeros siglos de la Hégira de manos de los geógrafos, al servicio de los nuevos intereses surgidos, más allá del simbolismo. A pesar del interés suscitado, no debemos olvidar que estos eruditos tampoco obtuvieron su información sobre el terreno sino a través de viajeros y comerciantes; y para algunos de sus datos todavía acudieron a fuentes de la Antigüedad como Ptolomeo, que aún no había sido redescubierto por los reinos cristianos europeos ${ }^{14}$, pero que fue profusamente utilizado por los musulmanes. Los primeros grandes informantes, al-Ya'qubi (s. IX) o Ibn Hawqal (s. X) se limitaron a unos pocos nombres como Gana, Kaw-Kaw o ciudades fronterizas en las rutas transaharianas. Habrá que esperar a Ibn Battuta, norteafricano del siglo XIV, para encontrar un viajero que realmente haya visitado los lugares que describe y convivido con sus gentes ${ }^{15}$.

Un seguidor hispano de los grandes geógrafos musulmanes de Oriente es alZayyat, el cual parece que vivió a principios del siglo XI en la región de Zaragoza. En su obra aparecen descritos los siete climas y las fuentes del Nilo, apoyándose directamente en Ptolomeo y repitiendo datos de al-Juwarizmi o al-Ya'qubi sobre Abisinia, Kaw-Kaw o los Zany. Y sobre Sudán (la Etiopía del mundo cristiano) reúne los tópicos clásicos: intenso calor, muchos desiertos, leones, animales feroces, habitantes desnudos, etc.. Aunque se desconoce cuáles fueron sus fuentes para esta región, lo que sí sabemos es que su obra fue aprovechada por al-Idrisi en el siglo $\mathrm{XII}^{16}$.

11 Los geógrafos musulmanes distinguían cuatro grandes zonas en Africa (exceptuando el norte de Africa y Egipto): Zandj (también Zany) en la costa oriental africana; Habasha, Abisinia, con capital en Kaw-Kaw; Nubia y Sudán, ésta última con una localización más imprecisa que las demás.

12 Una descripción anónima ..., p. 164.

13 Al-Hulal al-Mawsiyya. Crónica árabe de las dinastías almorávides, almohades y benimerín [traducción de A. Huici Miranda, Editora Marroquí, Tetuán, 1952], p. 23.

${ }^{14}$ La obra de Ptolomeo no fue traducida al latín hasta 1409. Ver, J. DEVISSE (ed.), L'ímage du noir... Vol. II, t. II, p. 86, n. 98.

15 IBN BATTUTA: A través del Islam [traducción de S. Fanjul, Alianza, Madrid, 1981].

16 AL-ZAYYAT, Ishaq ibn al-Hasan: Dikr al-Aqalim. Tratado de Geografía Universal [edición, traducción y estudio realizados por F. Castelló, CSIC-Inst. "Millás Vallicrosa» de $\mathrm{H}^{\mathrm{a}}$ de la Ciencia Árabe de la UB, Dpto. de Filología Semítica, 1989]. 
Será en Al-Andalus donde aparezca una de las primeras grandes aportaciones a la geografía de África. Al-Bakri, geógrafo cordobés de la segunda mitad del siglo XI, va a enriquecer considerablemente el saber de su tiempo. Apoyándose sobre todo en viajeros y comerciantes del norte de África describe prolijamente las rutas caravaneras transaharianas con datos precisos de lugares y tiempos. También son importantes sus datos históricos, a veces incluso casi coetáneos como la descripción del reino de Ghana y la conversión del soberano de Tekrur, sólo unos cuantos años antes del surgimiento del movimiento almorávide ${ }^{17}$ en este área. También aporta abundante información sobre la parte occidental de Bilad as-Sudan, el «país de los negros», con sus principales ciudades, las costumbres de sus habitantes y sus maravillas. Adolece quizás de la zona este, aunque conoce el reino de Kanem. $Y$ un dato curioso, reseña expresamente relaciones comerciales de los arrabaleros andalusíes ${ }^{18}$ con el África occidental ${ }^{19}$.

Frente a toda la riqueza que venimos describiendo para la parte andalusí peninsular, los reinos cristianos, tan inmersos en las luchas políticas contra el Islam, parecían no tener oídos por el momento para otras cuestiones, aún comprendiendo que no tenían ningún interés político ni comercial en el África negra. Estos siglos son realmente yermos en aportaciones y cualquier dato está coloreado de anacronía y estereotipos.

Por otra parte, en el siglo XII se inició en al-Andalus y el Magreb el género de rihla, literatura de viajes. Entre los autores que lo cultivaron destaca el valenciano Ibn Yubayr, cuya vida transcurrió durante el período de dominación del Imperio almohade en la Península y que sirvió de modelo para sus sucesores. La obra describe el viaje de peregrinación del autor a La Meca, el cual, en su itinerario descendió por el Nilo y se desplazó por Abisinia, cruzando el mar Rojo para llegar a la Península Arábiga. De ahí que su aportación a la geografía africana se circunscriba a la parte de Nubia y la actual Etiopía, una zona bastante desconocida para cualquier autor occidental de su tiempo ${ }^{20}$.

Dentro del género de viajes, también encontramos representantes entre la comunidad judía. Benjamín de Tudela realizó su periplo hacia Oriente entre 1165 y 1173 y entabló contacto con la zona de Nubia, Abisinia y los judíos de Quilón, puerto de la costa índica ${ }^{21}$. Aparte de los datos fehacientes, su descripción sigue es-

17 Recueil des sources arabes concernant l'Afrique occidentale du VIIle au XVIe siècle: Bilad al-Sudan [edición y traducción de J. M. Cuoq, CNRS, París, 1975], p. 4.

18 Habitantes de los arrabales o barrios que circundaban las ciudades andalusíes, donde se fueron configurando diferentes espacios en función de criterios profesionales (curtidores, herreros, alfareros, tintoreros, etc.).

${ }_{19}$ MONTEIL, Vincent: «Al-Bakri: Routier de l'Afrique blanche et noire du Nord-Ouest (Cordove 1068). Traduction nouvelle de seize chapitres", en: Bulletin de l'I.F.A.N., XXX, série B, $\mathrm{n}^{\circ} 1$ (1968), pp. 39-116, p. 43.

${ }^{20}$ IBN YUBAYR: A través del Oriente. El siglo XII ante los ojos [introducción y traducción a cargo de Felipe Maíllo Salgado, Ediciones del Serbal, Barcelona, 1988].

21 TUDELA, Benjamín de: Libro de viajes [traducido por J. R. Magdalena, Ed. trilingüe, Gobierno de Navarra, 1994], pp. 193-95. 
tando empañada del relato bíblico y los tópicos propios de las fuentes cristianas: vuelve a insistir en la idea de los etíopes como los esclavos negros hijos de Cam, terrible tergiversación del pasaje de Noé, que fundamentará en la Modernidad la trata negrera.

En la línea clásica de descripciones del mundo, Al-Andalus también aportó en el siglo XII la obra del geógrafo al-Zuhri. Su información tiene muy diverso origen, desde fuentes de autores árabes para las zonas dominadas por el islam oriental, hasta datos contrastados por él mismo para el caso de Al-Andalus. Desgraciadamente, la región menos rigurosa es la que atañe al mundo no musulmán, en el que se incluye el África subsahariana, donde los datos son incompletos, vagos y muchas veces confusos. Sin embargo, es una de las primeras fuentes hispanas que nombra Guinea (Yanawa) como sinónimo de los pueblos negros de la zona occidental africana, en lugar de Sudán².

\section{LA CONSOLIDACIÓN DE LOS REINOS CRISTIANOS PENINSULARES}

A medida que avanzaba el siglo XIII, Europa fue conociendo una nueva etapa de aperturismo en el pensamiento, siendo algunas de sus manifestaciones el movimiento de las Cruzadas, las órdenes mendicantes y el comienzo de la expansión marítima en el Mediterráneo. Como consecuencia de ello, también se empiezan a encontrar nuevas visiones respecto a África, así, la aparición del rey mago negro o la africanización de San Mauricio son símbolos de los primeros intentos de universalización del mensaje cristiano a toda la humanidad conocida hasta el momento ${ }^{23}$.

De forma paralela, en la Península Ibérica la expansión estaba siendo llevada a cabo a través de varias corrientes. La primera de ellas, la militar, contra los reinos andalusíes, que poco a poco iban cediendo su espacio político y religioso a los beligerantes reinos cristianos del norte. Junto al proyecto político, monarcas como Alfonso $\mathrm{X}$ dieron cabida también a una apertura hacia otros universos culturales como el oriental e islámico, de la que es ejemplo la Escuela de Traductores de Toledo. Habría cabido esperar que este movimiento hubiera permitido entrar en las fuentes cristianas el caudal de información sobre África subsahariana que se venía acumulando desde hacía siglos incluso en el propio suelo peninsular. Sin embargo, cuando nos acercamos a la magna obra del rey sabio llegamos a la triste conclusión de que muchos de los cambios producidos sólo tenían como pretensión la reafirmación y consolidación ideológica de la conquista contra Al-Andalus, pero en otros planos las informaciones siguen estando necrosadas y, de hecho, los africanos son descritos como gentes «sin reino, sin ley,

22 Al-ZUHRI, Muhammad b. Abi-Bakr al-: El mundo en el siglo XII. Estudio de la versión castellana y del 'original' árabe de una geografía universal: El tratado de al-Zuhri [Barcelona, 1991], pp. 114-161.

23 DEVISSE, J. (dir.): L'image du noir... vol. II, t. 1, cap. III. 
sin ciencia ni saberes, sin entendimiento 24 . Como mucho, las obras aluden a los datos históricos del Islam en la Península lbérica, donde aparecen negros en los ejércitos, pero sigue sin asomar el interés por el continente por sí mismo: el África real parece no existir.

\section{HACIA UN NUEVO UNIVERSALISMO Y LOS INICIOS DE LA EXPANSIÓN MARÍTIMA}

Avanzando en el siglo XIV es importante destacar las obras de carácter histórico realizadas por historiadores andalusíes. A pesar de que sus escritos no pretenden abarcar más allá del norte de África, queda patente que la relación con Sudán existía, era continua y tenía su relevancia para los reinos musulmanes magrebíes y andalusíes. Quizás no sean demasiadas las aportaciones puntuales que realizan estos autores, pero dotan de plena historicidad al África occidental subsahariana, en total oposición a la visión atemporal e imaginaria que todavía se transmite en los reinos cristianos peninsulares y, por supuesto, en el resto de la cristiandad europea.

Ibn Marzuq, enviado del sultán benimerín a Castilla tras la batalla del Salado (1340), realiza en su obra una especie de panegírico regio y parte de ella tiene gran interés histórico positivista. Nombra al sultán contemporáneo de Malí, Sulayman b.Musa y el intercambio de regalos con el sultán magrebí ${ }^{25}$, lo cual hace presuponer relaciones políticas frecuentes y fluidas en esta etapa. Del mismo modo, Ibn al-Jatib, discípulo del anterior, dedica la mayor parte de su obra a la etapa de los almorávides, incluyendo numerosas referencias a las relaciones de éstos con la zona sudanesa ${ }^{26}$.

Si bien en la Baja Edad Media europea la expansión política, comercial y religiosa fueron de la mano, en la Península lbérica este papel fue desempeñado de forma diferente según las zonas. Por un lado, la órbita castellano-leonesa mantuvo en estos siglos su esfuerzo por la conquista política de los reinos musulmanes todavía no sometidos. Por otra parte, las coronas catalana y aragonesa, sin mayor posibilidad de expansión interna hacia el sur, pasaron a protagonizar una espectacular carrera económica y marítima a través del Mediterráneo e, incipientemente, hacia el Atlántico. Asimismo, en la creciente y ya imparable aspiración del cristianismo a la universalización de su mensaje, jugaron también un papel relevante las órdenes mendicantes. Desde el siglo XIII ya se tiene constancia de la

${ }^{24}$ ALFONSO X: Libro de las cruzes [edición a cargo de Lloyd A. Kasten y Lawrence B. Kiddle, CSIC, Madrid-Madison, 1961], pp. 6-7.

${ }_{25}$ IBN MARZUQ: El 'Musnad': hechos memorables de Abu l-Hasan, sultán de los benimerines [estudio, traducción, anotación e índices anotados por María J. Viguera, Instituto Hispano Arabe de Cultura, Madrid, 1977], 113r.

${ }^{26}$ IBN al-JATIB: Kitab a`mal al-a`lam [traducción, notas e índices de R. Castrillo, Instituto Hispano Arabe de Cultura, Madrid, 1983]. 
presencia de franciscanos en el norte de África, en estrecha relación con la expansión catalana en el Magreb.

A la luz de estos nuevos intereses se despierta la necesidad de conocer otras regiones antes relegadas al oscurantismo. Se abría paso de este modo una nueva corriente evangelizadora de tono pacífico, que pretendía la comprensión de otras religiones para favorecer primero el entendimiento mutuo y después la conversión del Islam al cristianismo. Dentro de dicha corriente encontramos la obra del maIlorquín Ramón Llull, que vivió en la segunda mitad del siglo XIII. Recibió una esmerada educación y su espíritu (pre)humanista le llevó a fundar un colegio de lenguas para la traducción de libros extranjeros, sugiriendo incluso al Papa la enseñanza en las escuelas del árabe, hebreo, griego y caldeo. Su voluntad evangelizadora trascendía el mundo islámico y se aventuró a proponer la cristianización también de pueblos adoradores de ídolos como los habitantes de Gana ${ }^{27}$.

No podemos finalizar la Edad Media sin destacar el papel desempeñado por la escuela cartográfica de Mallorca. La carrera comercial marítima hacía necesario el desarrollo de una moderna concepción de la representación del mundo y de los portulanos, si bien es cierto que todavía nos encontramos en una fase de transición. Estamos ante los primeros pasos de la expansión atlántica que se verá realizada en el siglo siguiente con la circunnavegación de África por los portugueses y la llegada a América por los españoles. En este sentido es destacable la obra del mallorquín Abraham Cresques y su mapamundi realizado en el año 1375. Para los datos aportados para la parte subsahariana occidental, Cresques pudo contar con la información de expediciones realizadas hacia el Atlántico a lo largo del siglo, entre ellas las leyendas de cartas náuticas como las de Giovanni de Carignano que tomó noticias de un comerciante genovés del siglo XIV ${ }^{28}$; aunque hay autores que defienden que tuvo acceso, directa o indirectamente, a la obra de Ibn Battuta escrita pocas décadas atrás ${ }^{29}$. En el mapa aparece dibujado el rey de Malí con una enorme pepita de oro en su mano que simboliza el comercio transahariano con esta región. A su lado Cresques escribe: «este rey negro se llama Musa y es soberano de los negros de Guinea. Es el más rico y noble soberano de toda esta región debido a la abundancia de oro que se extrae en su país»30.

Un salto cualitativo en los datos descritos lo representa sin duda el Libro del conosçimiento de todos los reynos. Inscrito quizás en el género de literatura de viajes, supuso un incremento notable de información sobre el África occidental y su costa. Aunque los primeros estudios daban como fecha de redacción 1350, investigaciones posteriores quieren situarlo en fecha más tardía, hacia 1390. Tam-

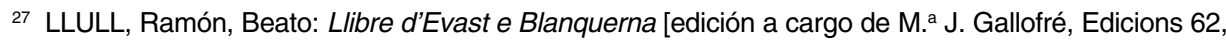
Barcelona, 1982], p. 238.

${ }^{28}$ FALL, Yoro K.: L'Afrique à la naissance de la cartographie moderne. Les cartes majorquines: XIVeXVe siècles, Karthala, Centre de recherches africaines, París, 1981, p. 163.

${ }_{29}$ Mapamundi del año 1375 de Cresques Abraham y Jafuda Cresques [edición a cargo de VV. AA., SA EBRISA. Barcelona, 1983], XXXII.

30 Ídem, p. 45. 
poco la autoría está bien determinada. Atribuida durante tiempo a un monje franciscano, hoy parece que no pueden encontrarse fuentes fidedignas que corroboren esta afirmación, aunque sigue sin poder establecerse la identidad del escritor $^{31}$. La obra describe tres viajes, el último de ellos a la «tierra de negros», o sea, a las zonas del Sáhara, Guinea y Angola. A pesar de la verosimilitud que implica la utilización de la primera persona en la narración de todo el relato, la amplitud de las rutas que describe y la falta de detalles prácticos de las mismas, inclina a pensar que no se trata de un viajero real sino, como en anteriores ocasiones, de una recopilación de fuentes de diversa naturaleza ${ }^{32}$. El autor debió tener delante alguno de los mapamundis de mediados del siglo XIV y diversos portulanos de los que utiliza muchas veces literalmente sus leyendas, aunque son completadas con fuentes orales del norte de África y Al-Andalus coetáneas. Esto no evita que para algunos pasajes acuda otra vez a fuentes medievales antiguas entremezclando todavía visiones anacrónicas de los pueblos africanos. A lo largo de casi toda la obra el autor utiliza el término Guinea para referirse al área subsahariana, terminología que se impondrá de ahora en adelante en sustitución de Etiopía, también nombrada profusamente, que se referirá junto a Nubia al área oriental del continente, coincidiendo más o menos con la verdadera Etiopía histórica. A esta zona dedica varios capítulos, remarcando el carácter cristiano de sus gentes: «son negros pero son omes de buen entendimiento e an saberes e ciencias". La obra tuvo gran difusión en su época, en la Castilla del siglo XV e incluso fuera de las fronteras de los reinos hispanos.

Más africano que hispano habría que considerar a al-Hasan b.Muhammad alWazzan al-fasi al-Garnati, Juan León Africano, nacido a finales del siglo XV en Granada y cuya familia se vio obligada a exiliarse poco después a Fez ante la conquista cristiana de su ciudad en 1492. Visitó Tombuctú a los dieciséis años acompañando a su tío y posteriormente entró al servicio del último sultán benimerín, obligándole su cargo a viajar por todo el Magreb, llegando hasta Egipto y Constantinopla. En un segundo viaje volvió a Tombuctú, esta vez parece que en un viaje comercial privado, dirigiéndose después de Egipto, pasando por Djené, Walata, Gao y Kano ${ }^{33}$. El interés de su obra se centra en el África musulmana de ahí que nos ofrezca una detallada descripción del norte de África donde se entremezclan referencias al sur sahariano sobre todo por sus relaciones comerciales con el norte. Su mayor valor está en aportar datos contemporáneos que sacan al África negra de la atemporalidad presente en casi todos los textos anteriores.

${ }^{31}$ Libro del conosçimiento de todos los rregnos et tierras et señorios que son por el mundo, et de las señales et armas que han [ed. facsimilar del manuscrito Z, edición y estudio de M. a Jesús Lacarra et al., Institución «Fernando el Católico», CSIC. Zaragoza, 1999], p. 80.

32 Ídem, p. 83.

${ }^{33}$ AFRICANO, Juan León: Descripción general del Africa y de las cosas peregrinas que allí hay, [traducción, introducción y notas a cargo de Serafín Fanjul, Lunwerg, Barcelona, 1995]. 


\section{LA MODERNIDAD Y LA EXPANSIÓN ATLÁNTICA}

Los comienzos de la Modernidad en la Península vienen marcados por el fenómeno de la expansión atlántica. Ahora son los súbditos de la Corona hispánica los que acuden directamente a África, proporcionando información de primera mano a los eruditos, cuando no son ellos los que residen largas temporadas en el continente. En este momento se escriben descripciones que nos hablan del mayor conocimiento de la geografía y de los pueblos que habitan la zona subsahariana. Nos trasmiten una gran riqueza de detalles, que con el transcurrir del tiempo será cada vez mayor. Estos estudios tienen como objetivo un posible aprovechamiento económico o político de la zona por parte del Estado o de los comerciantes que mantienen lazos con ella. Las monografías se agrupan en tres corrientes principales: la geografía, la esclavitud y las posibilidades de evangelización.

Una gran parte de la información llega a través de las noticias y libros que los portugueses trasmiten, pero también de la presencia de españoles en esos viajes, así como de fuentes árabes. La unión de España y Portugal entre 1580 y 1640 proporcionó un gran volumen de información a los autores españoles sobre África. En general, son estudios que se centran en la costa africana, aunque a veces realizan alguna precisión sobre cierta zona del interior como el Congo, el reino del Monomotapa o Etiopía.

Uno de ellos es el de Martín Fernández de Enciso, que en 1519 contribuye con su Suma de Geographia a ese conocimiento ${ }^{34}$, alejando las creencias de hombres monstruosos en el África austral, para lo que se basa en la experiencia misionera y en el testimonio de los comerciantes árabes. No todos los datos que proporcionan estos autores son correctos, porque todavía se tiene sólo un relativo conocimiento de la zona. Un buen ejemplo es otro autor granadino, Luis de Mármol Carvajal, quien escribe y publica su Descripción General de África, entre 1573 y $1599^{35}$. Recorrió el norte de África hasta Egipto, por lo que dispone de una mayor precisión para esta zona geográfica. Sin embargo, también es bastante certera su narración entre el Río Senegal y Sierra Leona, así como de Etiopía y su interés por el Congo cristiano. Sobre la costa del África austral y oriental, su descripción es más escueta y casi nula para el interior del continente.

Por otra parte, sobre el Sahel también se recogen noticias más o menos ambiguas que describen la ruta entre Marruecos y la curva del Río Níger. Un ejemplo es la ya mencionada Descripción de León el Africano, pero también llegan a la Corte española descripciones de viajes realizados en esta zona, probablemente por

${ }^{34}$ FERNÁNDEZ DE ENCISO, Martín: Suma de geographia que trata de todas las partidas y provincias del mundo; en especial de las Indias y trata largamente del arte del marear; juntamente con la espera en romance; con el regimiento del sol y del norte; nuevamente hecha [ed. facsímil, Vicent García Editores, Valencia, 1999].

${ }^{35}$ MÁRMOL CARVAJAL, Luis del: Descripción General de África [Instituto de Estudios Africanos del Patronato «Diego Saavedra Fajardo», CSIC, Tomo I, Madrid, 1953]. 
españoles, a finales del siglo XVI y que describen con gran cantidad de detalles la ruta, realizada por el mismo narrador, entre Marrakech, Tegaza y Tombuctú ${ }^{36}$. El interés sobre el imperio songhay se renueva debido a que su rey envía una embajada al Xarife de Marruecos, por lo que los españoles estaban en disposición de saber de qué trataba ésta, y cuáles eran las intenciones tanto del sultán marroquí como del rey de songhay ${ }^{37}$. Además esta visita dispara la curiosidad sobre aquellas tierras, que estaban tan organizadas estatalmente como para llevar una embajada a Marruecos, cargadas con presentes de oro y ámbar.

En relación con Etiopía tenemos que mencionar la publicación en castellano realizada por Jacobo Cromberger, en la Sevilla de 1515, del libro de viajes Libro del Infante Don Pedro de Portugal, que gozó de una enorme popularidad. Su autor es Gómez de Santisteban, muy probablemente un clérigo español ${ }^{38}$. En ella narra el viaje, en gran parte imaginario, de Don Pedro, que parte desde Barcelos, pasando por Valladolid hasta la tierra del Preste Juan, con la descripción del reino, y su regreso, vía Fez hasta Castilla, donde finaliza el viaje ${ }^{39}$.

Sobre este reino circulan a lo largo del siglo XVI diversos libros de viajeros portugueses que habían estado en él. Algunos de ellos se traducen muy pronto al castellano. Quizás el más significativo es la Historia de las cosas de Etiopía, escrito por el portugués Francisco Álvares (titulado en portugués Verdadera Informaçam das terras do Preste Joam) en su estancia en ese reino entre 1520 y 1526 , y que traduce en Amberes Thomas Padilla en 1557. En la biblioteca del Palacio Real se conservan otras publicaciones del mismo libro de 1561 y de 1588 , esta última impresa en Toledo en casa de Pedro Rodríguez, mercader de libros ${ }^{40}$.

Asimismo, otro tema que sigue atrayendo la atención de los letrados españoles es el de las fuentes del río Nilo. Precisamente al primer europeo que contempló las fuentes del Nilo Azul, el jesuita español Pedro Páez, debemos una Historia da Etiopia, finalizada en 1620, y en la que narra la obra de los misioneros en aquellas tierras y la historia de ese reino, con gran detalle y relativa veracidad puesto que ha-

${ }^{36}$ Archivo General de Simancas (en adelante, A.G.S.), Guerra y Marina, leg. 127, 207. Aunque no figura el año de este viaje lo situamos a principios de los años ochenta del siglo XVI.

37 A.G.S., Guerra y Marina, leg. 130, 132. En carta de 12 de septiembre de 1582, firmada en Sanlúcar por el duque de Medina Sidonia, éste informaba al rey Felipe Il que había ido siempre procurando entender de qué provincia de Guinea había venido el «embajador de los negros» que se hallaba en Fez, y que aunque le había enviado una relación anterior no era tan puntual como la que con esta carta le enviaba, porque en ella se entendía de lo que había dicho el mismo embajador de Guinea. Por desgracia, no hemos podido encontrar ninguna de estas relaciones.

${ }_{38}$ SANTISTEBAN, Gómez de: Historia del Infante Don Pedro de Portugal, en la que se refiere lo que le sucedió en el viaje que hizo alrededor del mundo [Madrid, 1900].

39 NAVAS SÁNCHEZ ÉLEZ, María Victoria: «'Falsos amigos' y 'verdaderos amigos' en el Livro do Infante D. Pedro de Portugal (1644)», en Revista de Filología Románica, n²2, (2005), pp. 59-95. [en www.ucm.es/BUCM/revistas/fll/0212999x/artículos/RFM05051100].

40 ÁLVARES, Francisco: Historia de las cosas de Etiopía en la cual se cuenta muy copiosamente el estado y potencia del emperador de ella (que es el que muchos han pensado ser el preste Juan) con otras infinitas particularidades así de la religión de aquella gente, como de sus ceremonias, según que de todo ello fue testigo de vista Francisco Alvares, capellán del Rey don Juan Manuel de Portugal, Toledo, 1588. 
bía estado residiendo durante largos años en él ${ }^{41}$. Es, sin duda, una de las mejores, si no la mejor, reconstrucción de la historia de este reino durante la etapa Moderna.

También debemos destacar la obra de Fray Luis de Urreta Historia eclesiástica, política, natural y moral, de los grandes y remotos reinos de Etiopía, monarchía del Emperador Ilamado Preste Juan de las Indias, publicada en Valencia en 1610. En ella el dominico hace una descripción geográfica, política, religiosa y social de ese reino, nutriéndose de fuentes poco fidedignas aunque las presente como procedentes de Etiopía ${ }^{42}$. También publicará en 1611 en la misma ciudad Historia de la orden de Predicadores en Etiopía ${ }^{43}$. Precisamente una de las causas que había inspirado a Páez a escribir su Historia fue defender la verdad frente a las fabulaciones contenidas en la obra de Urreta ${ }^{44}$. En el mismo siglo XVII, José Antonio González de Salas, traductor de Pomponio Mela comentaba que las fuentes del Nilo se encontraban en el fin de Etiopía, donde llamaban El Cabo de Buena Esperanza, y no en el África Occidental, es decir, para él África abarcaba en una sola unidad tierras australes que para algunos autores clásicos estaban separadas del mundo conocido por el mar ecuatorial ${ }^{45}$.

Otra corriente de estudio por la que autores españoles muestran interés en los primeros siglos de la Modernidad es la de la esclavitud. No podía ser de otra forma, puesto que los esclavos fueron fluyendo de forma constante y creciente durante el siglo XVI y XVII a territorios como Andalucía, Canarias y sobre todo a la América hispana. Son trabajos que no se preocupan tanto por la historia o la vida de los pueblos africanos como de las condiciones en las que se desenvuelve el fenómeno de la trata, sobre todo en su vinculación con América, sobre la legitimidad o no de la esclavitud. En este sentido debemos mencionar a autores como Alonso de Sandoval, Fray Bartolomé de las Casas, Francisco de Vitoria, fray Domingo de Soto, don Bartolomé Frías de Albornoz o fray Francisco José de Jaca ${ }^{46}$. El mismo Tomás de Mercado en su conocida obra de Suma de tratos y contratos reflexiona en el subcapítulo llamado «Del trato de los negros de Cabo Verde», sobre el peso que el rey de Portugal tenía en las costas africanas y sobre las tropelías que se cometían en el comercio de esclavos para llevar a Indias ${ }^{47}$.

41 PAIS, Pero: História da Etiopía. Reproduçao do códice coevo inédito da Biblioteca Pública de Braga [Livraria Civilizaçao, Oporto, 1945-46].

${ }_{42}$ URRETA, Fray Luis de: Historia eclesiástica, política, natural y moral de los grandes y remotos reinos de Etiopía, monarchía del Emperador llamado Preste Juan de las Indias. Valencia, 1610.

43 URRETA, Fray Luis de: Historia de la sagrada orden de Predicadores en los remotos Reynos de la Etiopía. Valencia, 1611.

${ }_{44}$ ALFONSO MOLA, Marina y MARTÍNEZ SHAW, Carlos: «Pedro Páez y la misión jesuítica en Etiopía en el contexto de la unión de las Coronas de España y Portugal», en Espacio, Tiempo y Forma. Serie IV, 17 (2004), pp. 59-75, la referencia en p. 70.

${ }_{45}$ RELAÑO, Francesc: La emergencia de África como continente: un nuevo mundo a partir del viejo, Universitat de Lleida, 2000, p. 31.

${ }_{46}$ Ver ANDRÉS-GALLEGO, José: La esclavitud en la América española, Encuentro Ediciones, Fundación Ignacio Larramendi, Madrid, 2005.

47 MERCADO, Tomás de: Suma de tratos y contratos [Instituto de Estudios Fiscales, Ministerio de Hacienda, Madrid, 1977], vol. 1, pp. 229-239. 
La tercera corriente está representada por los textos que los misioneros capuchinos españoles realizaron en El Congo, Benín, Arda y Senegambia, sobre todo entre 1640 y 1665, tras la independencia de Portugal. Este renovado interés corre de la mano de los intereses políticos y económicos de Felipe IV, que, tras verse privado de las colonias africanas portuguesas, se plantea la posibilidad de crear sus propios establecimientos coloniales hispanos en el África subsahariana, idea que se abandonaría a su muerte. Quizás la más constante de estas misiones fue la Regnum Negritarum en el Reino del Congo que se traduce, entre otras, en la Missión Evangélica al Reyno del Congo, publicación efectuada en Madrid (1649) por parte de don José Pellicer de Tovar ${ }^{49}$. Al hilo de sus viajes, los misioneros también relatan las impresiones sobre esas regiones y de otras por las que iban transcurriendo, como su paso por las islas de Cabo Verde. También se describen los productos agrícolas y ganaderos que hallaban, las relaciones de poder entre la élite indígena, las guerras internas, la religión, las costumbres de estos pueblos, las enfermedades, las edificaciones, la presencia de otros europeos, etc. En general, en todos estos escritos de carácter misional está presente la percepción de bondad de los africanos y su predisposición para aceptar la doctrina católica, si bien a veces se critica la ambigüedad de sus autoridades. Quizás el hito más importante en cuanto a escritos se refiere fuese la preparación del catecismo titulado Doctrina Cristiana, escrito en español y egun (gun), la lengua de Allada, que con una forma muy simple intentaba hacer llegar y que fuese comprendida la doctrina católica por parte de los africanos. El catecismo está impreso en Madrid por Domingo García Morras y es el escrito más antiguo conocido de la lengua de la Costa de los Esclavos $^{50}$.

Como consecuencia de la acumulación de todos estos conocimientos la imagen de África y de los negros se va haciendo más frecuente en la modernidad española, aunque también continua estando distorsionada, con una visión tendente a recrear su posición de subordinada. Un buen ejemplo lo tenemos en la presencia de territorios como Etiopía o Guinea en varias obras de la literatura del Siglo de Oro (de manera anecdótica), como en El Quijote o en diversas obras de Lope de Vega.

\section{LA INFLUENCIA DE LA PRIMERA COLONIZACIÓN}

La llustración renueva el interés por la búsqueda de nuevos conocimientos, también por los africanos. Es por ello que en esta época proliferan en España los estudios botánicos y faunísticos y se organizan expediciones científicas que aseguren la captación de este saber. Un claro exponente de estos estudios lo constituye la figura del sevillano Francisco Noroña que, entre otros lugares visita la Isla

48 PELLICER DE OSAU Y TOVAR, José: Missión evangélica al reyno de Congo por la seráfica religión de los Capuchinos, Madrid, 1649.

49 LABOURET, Henri y RIVET, Paul: Le Royaume d'Arda et son Évangélisation au XVIle siècle, París, 1929, p. 20. En esta nota agradezco la amable colaboración del profesor José S. Gómez Soliño. 
Mauricio (Isla de Francia) y Madagascar en la segunda mitad del siglo XVIII50. Por otro lado, se abre en España el Real Jardín Botánico de Madrid en 1775 y el Jardín de Aclimatación de La Orotava en 1788 en Tenerife. No obstante, el interés de los ilustrados tampoco era filantrópico sino que iba acompañado de un claro pragmatismo que tendía, por un lado, a la aclimatación de especies con el objetivo de fomentar su producción y sus beneficios económicos, y, por otro, al conocimiento de futuras bases territoriales que sirviesen como trampolín al fomento del comercio con África, fundamentalmente de esclavos. España no hace más, por otra parte, que copiar el modelo que ya estaban aplicando desde hacía algunos años otras potencias europeas. En esta época España firma el tratado de San IIdefonso con Portugal en 1777, por la que ésta le cede las islas de Fernando Poo y Annobón.

En los siglos XVIII y XIX siguen presentes los temas relacionados con la esclavitud, debido a que desde finales del XVIII España incrementa su participación directa en el tráfico de seres humanos. Sin embargo, España también participará del debate de la abolición de la esclavitud contando con figuras tan excelsas como José María Blanco White. Este sevillano aborda el tratamiento del comercio de esclavos en su obra Bosquejo del Comercio de Esclavos, y Reflexiones sobre este tráfico considerado moral, política y cristianamente, publicada en $1814^{51}$. En ella, a pesar de reconocer los derechos que los españoles tenían sobre el tráfico de esclavos, aboga claramente por la abolición de la esclavitud. White estaba influenciado por los debates abolicionistas de las Cortes de Cádiz, en donde las ideas liberales de libertad e igualdad chocaban con los intereses coloniales de los españoles en América, fundamentalmente de Cuba y Puerto Rico. Además, también bebe sus ideas en los abolicionistas británicos de principios del siglo XIX a quienes conocía bien pues había residido en Inglaterra desde 1810. En su Bosquejo realiza una descripción de cómo se realizaba el tráfico esclavista y de la manipulación que los negreros hacían sobre los pueblos y estados africanos, sobre el carácter «humano» de los africanos, sobre las causas del atraso de África, relacionadas con el tráfico esclavista, sobre la falta de moralidad del tráfico esclavista, particularmente para los cristianos, sobre la concepción que de la esclavitud tenían los españoles y sobre su participación en ella a lo largo de la historia. Un poco más tarde, también queremos destacar la existencia entre 1865 y 1888 de la Sociedad Abolicionista Española, que editaba El Abolicionista.

Desde que se reanuda el proceso colonizador de España en África, teniendo como centros las colonias del Norte de Marruecos, Ifni, Sáhara y Guinea Ecuatorial, se demanda y así surgen una multitud de estudios que den cobertura ideológica al imperialismo español en este continente. En ellos se trata de justificar, los derechos históricos y «civilizadores» que España tenía para dominar estos terri-

50 PINAR GARCÍA, Susana: El sueño de las especias. Viaje de exploración de Francisco Noroña por las islas de Filipinas, Java, Mauricio y Madagascar, CSIC, Madrid, 2000.

51 Véase, BLANCO WHITE, José María: Bosquejo del comercio de esclavos [Alfar, Sevilla, 1999]. 
torios y aún otros que estaban en disputa. La tendencia se agudiza después del desastre del 98 y el nuevo impulso que se le quiere dar a la ocupación africana española.

El fundamento colonizador es el nexo de conexión de casi todos los trabajos que se realizan en estos momentos. En ellos raramente se pone interés sobre la propia historia o características de los africanos sino sobre el papel civilizador de la metrópoli, las descripciones geográficas y los aprovechamientos económicos de la colonia, siguiendo la corriente de pensamiento decimonónica que consideraba a los africanos como pueblos sin historia, por tanto incivilizados y, como consecuencia, susceptibles de ser colonizados ${ }^{52}$. Si acaso existe interés por algún aspecto autóctono éste será el de la gramática y vocabulario de los pueblos de la Guinea Ecuatorial, aunque su finalidad no sea la voluntad de conocimiento mutuo sino más bien el proyecto evangelizador. Por tanto, las ramas que se ocuparon de estos pueblos fueron la etnología, la antropología y la sociología, que dejaban de lado por completo la perspectiva histórica ${ }^{53}$. Incluso la influencia de las teorías del evolucionismo darwiniano también está presente. Entre los numerosos estudios desde la segunda mitad del siglo XIX hasta 1936 podríamos nombrar los de Ríos y Moros, Guillemar, Usera, Navarro, Muñoz, Negrín, Sanz, Torres, Sorela, Iradier, Coello, López Vilches, Montaldo, Beltrán y Rozpide, D’Almonte, Saavedra, Granados, Ramos, Río Joan, Unzueta, Valdés, Arija, Banciella, Nosti, Olmo, Báguena, Bravo Carbonell ${ }^{54}$, Martínez y Sanz, Ferrer Piera, Rodríguez Barrera, etcétera.

Este tipo de estudios proliferan a lo largo del siglo XIX y XX, hasta casi la caída del régimen franquista. Según esta línea argumental los africanos habían vivido en la espesura de la selva o en la sabana hasta la llegada de los europeos. Incluso en la década de los 70 del siglo XX se escribía todavía "África iba a quedar al descubierto con sus grandes lagos, sus caudalosos ríos, sus montes y cataratas, sus fieras y sus hombres. Sobre todo sus hombres. Tribalismo, costumbres ancestrales y bárbaras, religiones extrañas y un estancamiento en su vivir primitivo. Ahí estaba detenida su existencia, entre murallas de árboles gigantes, en la espesura verde del silencio. Hombres negros, en una libertad reducida y con fronteras limitadas a veces al clan, al claro del bosque que adorna con toscas chozas de nipa» ${ }^{55}$.

En otro orden de cosas, a finales del siglo XIX se crean diversas sociedades geográficas como la Sociedad Geográfica Española en 1876. La Asociación Española para la Exploración y Civilización del África Central se constituye en noviembre de 1876, como una rama española de la Asociación Internacional homó-

52 HEGEL, Georg Wilhelm Friedrich: Lecciones sobre la filosofía de la Historia Universal [Tecnos, Madrid, 2005], p. 279.

53 BURGUIĖRE, André: Diccionario de Ciencias Históricas. Ediciones Akal, Madrid, 1991, p. 11.

${ }^{54}$ CORDERO TORRES, José María: El africanismo en la cultura hispánica contemporánea, Ediciones Cultura Hispánica, Madrid, 1949, p. 67.

55 SÁEZ DE GOVANTES, Luis: El africanismo español, Instituto de Estudios Africanos, CSIC, Madrid, 1971 , pp. $15-16$. 
nima creada en Bruselas por Leopoldo II de Bélgica, y cuyo primer presidente sería el propio Alfonso XII. La capacidad de Joaquín Costa posibilita en 1883 la creación de la Sociedad Española de Africanistas y Colonialistas y su apoyo a diversas expediciones a Guinea y Sáhara. En noviembre de 1912 se constituye en Madrid, en el senado, la Liga Africanista Española, tras aceptar España las responsabilidades marroquíes. Estas instituciones fomentan expediciones por todo el continente y además surgen numerosas publicaciones periódicas que siguen teniendo un interés especial por Marruecos. Al mismo tiempo, nacen publicaciones de prensa como El Eco de Fernando Poo, en Santa Isabel en 1900 o la revista claretiana La Guinea Española en $1903^{56}$.

\section{LA DICTADURA FRANQUISTA}

Los estudios de apoyo a las pretensiones del colonialismo español se acentúan aún más durante el periodo de la dictadura franquista. Abundan los trabajos sobre esta geografía, pero con unas características concretas que eran reflejo del retraso con respecto a lo que estaba ocurriendo en el resto de Occidente. Apenas se escribió ninguna obra de carácter científico que aglutinara a la totalidad del África subsahariana, a diferencia de lo que ocurría en la misma época en países como Francia, Gran Bretaña o Estados Unidos. Sigue presente, y hasta cierto punto es mayor, el objetivo evangelizador y religioso del «pueblo elegido» (los españoles) de cara a su «ejemplar» tarea con los africanos. La mayor parte de los trabajos continúan centrándose en Marruecos y, dentro del África subsahariana, en la colonia de Guinea Ecuatorial. Son comunes las publicaciones, como por ejemplo a través de la Dirección General de Marruecos y Colonias, sobre aprovechamientos económicos, fundamentalmente agrícolas, de Guinea. En cualquier caso, son estudios sobre «nuestra África», en referencia al África española ${ }^{57}$. Obviamente, se seguían en general las tesis oficiales con respecto a los pueblos africanos.

También en esta etapa cabe hacer mención a los estudios que parten desde la Iglesia y sobre todo desde su obra misional, en la que queremos hacer mención a la revista Mundo Negro a partir de su creación en 1960, a iniciativa del misionero comboniano italiano P. Enrique Faré. Destacamos, no obstante, algunos trabajos que se realizan desde el ámbito científico y de la universidad a partir de finales de la década de los 50, y anteriormente los que ven la luz a través del Instituto de Estudios Políticos, creado en 1945 y adscrito Consejo Superior de Investigaciones Científicas (CSIC) , con diversas secciones de Geografía física, Geología, Edafología, Geografía humana, Etnología, Arqueología y Arte, Botánica, Antropología,

56 DARIAS DE LAS HERAS, Victoriano: «El africanismo español y la labor comunicadora del Instituto de Estudios Africanos», Revista Latina de Comunicación Social, año 5, n 46 (2002), [http://www.ull.es/publicaciones/latina/2002/latina46enero/4601darias.htm]

57 Para las publicaciones que se han realizado sobre Guinea Ecuatorial, antes y después de su independencia, es indispensable la consulta de www.jcmcrhp.net/libros.htm. 
Medicina, Farmacognosia, Entomología, Estudios Árabes, Estudios Marroquíes, Estudios Hebraicos, Historia, Economía y Derecho ${ }^{58}$.

Para coordinar los estudios africanos especializados se crea en junio de 1945 el Instituto de Estudios Africanos, que figura adscrito al Patronato «Saavedra Fajardo", a su vez dependiente de la Secretaría del CSIC, cuyo volumen de publicaciones fue considerable. Antes de la Guerra Civil esta labor había correspondido a la Junta para Ampliación de Estudios e investigaciones Científicas (JAE). El Instituto de Estudios Políticos lanza en 1946 sus Cuadernos de Estudios Africanos, que se reconvierten en 1956 en Cuadernos de Estudios Africanos y Orientales ${ }^{59}$. También se crea el Museo de África montado en los locales de la Dirección General de Plazas y Provincias Africanas y dependiente del Instituto de Estudios Africanos. En esta época destacan las figuras de José María Cordero Torres, Juan Fontán y Lobé y Juan Bravo Carbonell, este último con varias publicaciones sobre Guinea Ecuatorial antes y después del golpe de Estado del 36. Otros autores, que también habían realizado su labor antes de la dictadura, son Jaime Nosti, Abelardo de Unzueta y Yuste, José Olmo Boullón, Agustín del Saz, Juan Bonelli y Rubio, Pedro Fuster Riera, Manuel Lombardero Vicente, Román Perpiñá Grau, Juan Capdevielle San Martín, Manuel Cencillo de Pineda, José Díaz de Villegas, Emilio Guinea, Manuel Báguena Corella, José Esteban Vilaró, Cristóbal Fernández o Juan Miguel Zaragoza. Muchos de estos personajes realizan viajes a África, particularmente a Guinea Ecuatorial, como funcionarios, misioneros, militares o simples viajeros, casi siempre complacientes y cercanos al poder franquista, cuando no formaban parte de su maquinaria.

Es justo en la segunda mitad de la dictadura franquista cuando se va imponiendo otra idea con respecto a los territorios colonizados y al papel de España como potencia colonizadora que sustituye a la decimonónica. Se impone la defensa de que España no fue nunca colonialista sino colonizadora y civilizadora o en palabras de Sáez de Govantes «España, sin embargo, no supo ser colonialista y sólo le importaba el papel de colonizadora». De hecho, también en su papel con África, se impone el famoso eslogan de Spain is different, puesto que en palabras del mismo autor «lo africano va implícito en nuestra patria de siempre» o que España «se erigió en defensora de los valores espirituales sobre los materiales [...] España no acudió a África como a un segundo Cimarrón, a la subasta, a la carrera de la posesión cuando sonó el clarín del colonialismo y del reparto. España no participó jamás en ese juego por la forja de imperios inventado en la mesa europea. A los fríos propósitos de unas naciones que supieron ver mercados y ocasión de grandeza, a la «bandada de cuervos», no se sumó España» ${ }^{60}$. También en palabras de José María Martínez Val «en ningún caso, como hemos visto en los an-

589 CORDERO TORRES, José María: El africanismo en la cultura hispánica contemporánea, Ediciones Cultura Hispánica, Madrid, 1949, p. 27.

59 DARIAS DE LAS HERAS, Victoriano: «El africanismo español ...».

60 SÁEZ DE GOVANTES, Luis: El africanismo ..., pp. 46 y 27. 
teriores africanistas españoles, se trata de una dominación sobre la otra orilla del Estrecho. La intención es meramente de paz y hermandad, sobre el supuesto irrenunciable de nuestros derechos a lo que por razones de descubrimiento y ocupación ha sido nuestro ${ }^{61}$.

Ésto se produce justo en el periodo que la mayor parte de los países africanos están consiguiendo su independencia y en los que hay que preparar el camino de la descolonización española, representándose el Estado como madre patria que había tratado de cuidar de sus súbditos lo máximo posible. Los pilares de esa «civilización hispánica» eran por supuesto el catolicismo y la lengua castellana. El objetivo era perpetuar una relación de amistad y lograr futuras ventajas económicas tras la independencia. Extraemos el primer párrafo del libro de Cordero Torres titulado El africanismo en la cultura hispánica contemporánea, que pensamos es bastante significativo de este contexto histórico:

"La Historia enseña cómo la Divina Providencia se ha servido de algunos pueblos especialmente dotados para conducir a otros más atrasados por el espinoso camino de su crecimiento hasta que logren capacitarse para desenvolverse por sí en el concierto universal. España ha sido, y sigue siendo, uno de los pueblos privilegiados, que no ha rehuido la responsabilidad de servir de mentor y guía a las gentes más retrasadas, para entrar por las anchas vías de la civilización, que nosotros llamamos por antonomasia cristiana y que otros gustan de calificar de occidental, moderna o de origen europeo»62.

En este sentido debemos recordar la conversión en provincia de Guinea Ecuatorial a partir de 1956, la consecución de su autonomía en 1963 y finalmente su independencia en 1968, el año en el que también Ifni era cedido a Marruecos. En estos años otro tema que llama la atención de los estudios españoles es la no deseada posibilidad de que el comunismo prolifere en los recién independientes países africanos. Precisamente es en la década de los 60 cuando se crea en Madrid el Colegio Mayor Nuestra Señora de África, fundado por la Dirección General de Plazas y Provincias Africanas «para atender a la formación religiosa, moral y humana de los africanos ${ }^{63}$. El colegio actuará de punto de encuentro entre españoles y africanos y como difusor e impulsor de las investigaciones españolas sobre África a través de cursos, conferencias, seminarios, exposiciones y su importante biblioteca.

A finales de la dictadura se publica alguna obra de Historia general del África subsahariana $^{64}$. Una de las figuras de transición es la de Carlos González Eche-

61 MARTÍNEZ VAL, José María: Esquema histórico del africanismo español, en Cuadernos Didácti$\cos , n^{\circ} 376$, Publicaciones de la Revista Enseñanza Media, Madrid, 1958, p. 13.

62 CORDERO TORRES, José María: El africanismo en la cultura ..., p. 7.

${ }^{63}$ GÓMEZ-PALLETE, Manuel: El Colegio Mayor Nuestra Señora de África y su proyección sobre la cultura de los países africanos, CSIC, Madrid, 1968, p. 5.

${ }^{64}$ GONZÁLEZ ECHEGARAY, Carlos: Historia del África negra, Editora Nacional, Madrid, 1974. En la presentación de este libro se escribe «que viene a llenar un vacío en la bibliografía española del continen- 
garay, que vive durante años en Guinea Ecuatorial y desarrolla su obra tanto en el periodo de la dictadura como en el democrático.

\section{DE LOS INICIOS DE LA DEMOCRACIA AL PRINCIPIO DEL SIGLO XXI}

Es justo a partir de la llegada de la democracia cuando España intenta modernizarse también en los estudios africanos. Hay un intento por ocupar un hueco dentro de los estudios europeos, pero todavía la producción que se refiere al Norte de África sigue superando ampliamente en número a la que se dedica al África subsahariana. Aunque siguen publicándose trabajos sobre la relación de España con África, otros muchos se centran en los estudios exclusivamente africanos. De hecho, no sólo se escribe desde España sino que se acude y se investiga en África, se mantienen contactos regulares con universidades e investigadores africanos, e incluso se realizan numerosas tesis en territorio africano.

En las últimas décadas la internacionalización de los estudios ha sido aún mayor, gracias al contacto de africanistas con organizaciones africanistas internacionales y a la realización y promoción de proyectos conjuntos con investigadores de todo el mundo. Ya no sólo se aborda el tema desde el punto de vista de la Antropología, sino también de la Historia, la Geografía, la Sociología, la Filología, las Ciencias Políticas o la Economía, por poner algunos ejemplos.

El proceso de descolonización y los problemas de África para lograr un desarrollo económico equiparable al occidental y la estabilidad política están presentes en una buena parte de los estudios. Varios aspectos han actuado también como acicates del desarrollo de los estudios africanos, de los que ya hemos nombrado la necesidad de ponerse al día a nivel internacional, pero también otros como el impacto de la inmigración africana en las últimas décadas y la necesidad de conocer más acerca de los que llegan, el aumento de la cooperación internacional y también de los intereses económicos de las empresas españolas en todo el continente, sobre todo a través de los beneficios empresariales de sus cámaras de comercio o de multinacionales dedicadas a la extracción de recursos.

En la disciplina de Historia se observa una clara tendencia a abordar asuntos de relativa actualidad, cuando menos contemporánea, incluso en aquellos historiadores que en sus inicios realizaron sus primeras investigaciones sobre problemas pretéritos y ahora han adoptado una dimensión más comprometida. En los últimos años contamos incluso con obras de carácter general para la historia del continente, lo que refleja un profundo conocimiento de los asuntos africanos por parte de sus autores ${ }^{65}$. Más recientemente también se han realizado estudios de

te negro». Destacamos también dentro de Cuadernos de Estudio de la Delegación Nacional de Organizaciones, en la sección Seminarios, $\mathrm{n}^{\circ} 26$ monográfico dedicado a África. Madrid, 1964.

${ }^{65}$ CASTRO ANTOLÍN, Mariano L. y CALLE MUÑOZ, M. ${ }^{a}$ Luisa de la: Historia de África, Programa de Colaboración Educativa con Guinea Ecuatorial, MEC, Madrid, 1987; CORTÉS LÓPEZ, José Luis: Intro- 
la historia global del continente llevados a cabo por especialistas en diferentes áreas temáticas. Además, aunque los estudios regionales continúan estando dominados por el África Occidental y la costa guineana, ya no es infrecuente encontrar otros que se refieren a zonas hasta las últimas décadas inexistentes en los estudios africanos españoles como África Austral, África Oriental o la región del Índico.

En 1984 se crea la Asociación Española de Africanistas, que publicará a partir de 1985 la Revista de Estudios Africanos. También hay que destacar el Centro de Información y Documentación Africano (CIDAF) creado en los años 80 por los Padres Blancos y que en 2002 se ha transformado en la Fundación Sur, junto a Cáritas Española y Manos Unidas. En la biblioteca del CIDAF, situada en Madrid, se recogen más de 15.000 publicaciones relacionadas con la temática africana.

El Instituto de Estudios Políticos para América Latina y África (IEPALA), nacido en los años 50 ha continuado su labor durante décadas y ha tenido un papel destacado en la difusión de temas africanos, ya en la época democrática. Desde 1990 es un instituto universitario de la Universidad Complutense de Madrid que cuenta con varios títulos propios sobre cooperación, desarrollo, conflictos, género... También ha venido publicando periódicamente la revista África Internacional, además de otras publicaciones. Lo mismo se puede decir de la revista ÁfricaAmérica Latina, por parte de SODEPAZ, cuya labor ya había sido resaltada a finales de los ochenta y principios de los noventa de la centuria pasada ${ }^{66}$. También viene actuando y apoyando publicaciones la Asociación Africanista «Manuel Iradier» de Vitoria.

\section{ACTUALIDAD}

En las últimas décadas los autores que vienen trabajando temas africanos en las distintas variantes del pensamiento humanístico se cuentan por decenas. Tal como indicamos en el inicio de este artículo no queremos presentar una recopilación exhaustiva de los mismos sino ofrecer las líneas generales de investigación en la actualidad. Por esta razón, creemos más interesante nombrar los principales centros que están abordando temáticas africanistas con cierta regularidad, concentrándonos en el ámbito universitario, e indicando a sus principales representantes.

ducción a la Historia de África Negra, Espasa-Calpe, Madrid, 1984; INIESTA, Ferrán: El planeta negro. Aproximación histórica a las culturas africanas, Los libros de Catarata, Madrid, 1992; y del mismo autor: Kuma. Historia del África negra, Edicions Bellaterra, Barcelona, 1998; y Emitai. Estudios de historia africana, Edicions Bellaterra, Barcelona, 2000.

66 MARTÍNEZ CARRERAS, José Urbano: «La 'Historia de África' en la Universidad española», en Cuadernos de Historia Contemporánea, n 18, (1996), pp. 193-198, p. 194. 


\subsection{Barcelona}

Uno de los principales investigadores del africanismo español de los últimos treinta años es Ferrán Iniesta. Inició su labor como profesor en las universidades de Cheik Anta Diop (Senegal) y Antananarivo (Madagascar). En la actualidad, es profesor titular de Historia de África del Departamento de Antropología e Historia de América y de África de la Universidad de Barcelona ${ }^{67}$. Otros investigadores destacados son Alfred Bosch, profesor de Historia de África en la Universidad Pompeu Fabra de Barcelona, que ha trabajado la temática de Historia e identidades en África negra; Jacint Creus, doctor en Antropología e Historia de África, que ha concentrado sus esfuerzos en Literatura oral africana y ha sido fundador de "Ceiba», organización que se ha preocupado por impulsar los estudios sobre Guinea Ecuatorial y de dirigir las Jornadas Internacionales sobre Oralidad Africana; Alberto López Bargados, profesor de Antropología Social en la Universidad de Barcelona; Albert Roca, profesor de Antropología de la Universidad de Lleida, que ha desarrollado aspectos de la historia de África y los procesos de democratización en ese continente; es también director de la revista Studia Africana, revista interuniversitaria d'estudis africans, una de las publicaciones científicas sobre África con más calidad en nuestro país; y Tony Castel, profesor de Periodismo de la Universidad Autónoma de Barcelona y director de Nova Africa, revista de divulgación sobre la actualidad africana con más de once años de andadura, en la que publican autores tanto españoles y europeos como africanos ${ }^{68}$.

Este equipo de profesores viene desarrollando varios cursos que son una auténtica cantera para los estudios africanistas. Debemos destacar en el CIDOB, «EI mundo africano: las sociedades negroafricanas en la hora global», módulo optativo dentro del Máster en Estudios para el Desarrollo y el Máster en Estudios Internacionales. Vinculado al ámbito universitario, contando con algunos de los profesores citados, es importante destacar la labor realizada por el Centre d'Estudis Africans (CEA) orientado a la divulgación y centrado también en la actualidad en el tema de la inmigración. Organiza anualmente el Diploma Universitario de Postgrado en Sociedades Africanas y Desarrollo junto a la Universitat Pompeu Fabra, además de muchas otras actividades de difusión abiertas a todo tipo de público.

67 A continuación señalamos algunas de las obras más destacadas de estos autores INIESTA, Ferrán: Bajo la Cruz del Sur. Religión, comercio y guerra en el canal de Mozambique (900 a 1700 d.c.), Sendai, Barcelona, 1993; y ROCA, Albert (ed.): Africa en la frontera occidental, Sial Ediciones, Madrid, 2002.

${ }_{68} \mathrm{BOSH}$, Alfred y CASTEL, Antoni (Coords.): El Africa que viene, Intermón, Barcelona, 1999; CREUS, Jacint y NERÍN, Gustau: Estampas y cuentos de la Guinea española, Clan, Madrid, 1999; CREUS, Jacint: Curso de literatura oral africana. Lecturas comentadas de literatura oral de Guinea y del África negra, Ceiba ediciones, Barcelona, 2005; LÓPEZ BARGADOS, Alberto: Arenas coloniales. Los Awlad Dalim ante la colonización franco-española del Sáhara, Ediciones Bellaterra, Barcelona, 2003; ROCA ÁLVAREZ, Albert (ed.): La revolución pendiente. El cambio político en el África negra, Universitat de Lleida, Lleida, 2005. 


\subsection{Madrid}

A finales de los años 70 y principios de los 80 se formó un nutrido grupo formado por africanos venidos a Madrid en torno a la figura de Luis Beltrán ${ }^{69}$, profesor de Ciencia Política en la Universidad de Alcalá de Henares, que sería nombrado posteriormente director del Colegio Mayor Universitario Nuestra Señora de África. Este grupo desarrolló en esta época una importante labor de sensibilización. Entre ellos se encontraba Mbuji Kabunda Badi ${ }^{70}$.

En la Universidad Complutense sobresalió el fallecido José Urbano Martínez Carreras $^{71}$, profesor que fue del Departamento de Historia Contemporánea. Impartió asignaturas sobre historia de África y Asia y fue Presidente de la Asociación Española de Africanistas desde 1991 hasta 2003.

En la Universidad de Alcalá de Henares, en la actualidad, trabaja Landry-Wilfrid Miampika, profesor de filología francesa y crítico literario, que aborda principalmente la literatura francófona; y por supuesto José Manuel Pedrosa, profesor de Literatura Comparada y gran estudioso de la tradición oral en Africa ${ }^{72}$.

En la Universidad Autónoma de Madrid destacamos a Francisco Javier Peñas, profesor titular de Relaciones Internacionales y a Antonio Santamaría Pulido, profesor de Economía, ambos fundadores del Grupo de Estudios Africanos (GEA) en los años 90 que ha fomentado la labor difusora de temas africanos y cuenta actualmente con una buena cantera de investigadores. Fruto del trabajo del grupo es el Máster de Relaciones Internacionales y Estudios Africanos de la UAM. Entre los miembros más sobresalientes del grupo y también cofundador del mismo está Mbuyi Kabunda Badi, de origen congoleño, en sus inicios profesor de Relaciones Internacionales en la Universidad Patricio Lumumba, fue presidente de SODEPAZ en España y hoy en día reparte su labor entre el Instituto de Derechos Humanos de Estrasburgo y la impartición de cursos en diversas universidades españolas. Su obra, inmensa, se centra en las relaciones internacionales y en las propuestas de desarrollo. De la Universidad Autónoma debemos citar también a Itziar Ruiz-Giménez, profesora de Relaciones Internacionales y especialista en conflictos e intervención humanitaria en África, y a Alicia Campos Serrano ${ }^{73}$, también profesora

69 BELTRÁN, Luis y POLLAK-ELTZ, Angelina: Repertorio Internacional de Especialistas en la «africana" (Estudios Afro-Iberoamericanos-2001-. Cátedra UNESCO de Estudios Afro-Iberoamericanos, Universidad de Alcalá y Universidad Católica Andrés Bello, Alcalá de Henares, 2001.

70 KABUNDA BADI, Mbuji: Derechos humanos en África. Teorías y prácticas, Universidad de Deusto. Bilbao, 2000; KABUNDA, M. (coord.): África subsahariana ante el nuevo milenio, Ediciones pirámide, Madrid, 2002.

71 MARTÍNEZ CARRERAS, José Urbano: Los imperios africanos, Historia 16, Madrid, 1985; y África subsahariana (1885-1990). Del colonialismo a la descolonización, Editorial Síntesis, Madrid, 1993.

72 MIAMPIKA, Landry-Wilfrid: Voces africanas. Poesía de expresión francesa, 1950-2000, Verbum ediciones, Madrid, 2008; PEDROSA BARTOLOMÉ, José Manuel y ESTEPA PINILLA, Luis: Mitos y Cuentos del Exilio de Ruanda, Sendoa, Oiartzun, 2001.

73 RUIZ-GIMÉNEZ, Itziar Las buenas intenciones: intervención humanitaria en África, Icaria, BarceIona, 2003; CAMPOS SERRANO, Alicia: De colonia a Estado: Guinea Ecuatorial, 1955-1968, Centro de 
de Relaciones Internacionales, con una amplia experiencia en la descolonización en Guinea y los recursos naturales en África.

La actividad de los miembros del GEA se ha plasmado, de la misma forma, en la participación periódica en diversos másters relacionados con África en otros centros y universidades madrileñas:

- Magister en Cooperación Internacional, Instituto Universitario de Desarrollo y Cooperación, Universidad Complutense de Madrid.

- Curso de Extensión Universitaria Desigualdad, Cooperación y Desarrollo, Grupo de Estudios del Desarrollo (GED) y Dpto. Economía Aplicada I, Economía Internacional y Desarrollo, Universidad Complutense de Madrid.

- Programa de Altos Estudios en Desarrollo y Ayuda Internacional, Instituto Complutense de Estudios Internacionales, Universidad Complutense de Madrid.

- Máster en Cooperación Internacional y Gestión de Proyectos, Instituto Universitario de Investigación Ortega y Gasset, Madrid.

- Máster de Cooperación, Instituto Universitario de Estudios sobre Migraciones, Universidad Pontificia de Comillas.

\subsection{País Vasco}

Una buena parte de los estudios africanistas están impulsados por el Instituto de Estudios sobre Desarrollo y Cooperación Internacional (HEGOA). Entre sus miembros está Karlos Pérez de Armiño, profesor titular de Relaciones Internacionales en la Universidad del País Vasco; Eduardo Bidaurratzaga Aurre, profesor de Economía de la Facultad de Ciencias Sociales y de la Comunicación en la Universidad del País Vasco, que se ha dedicado a la temática de integración económica regional en Africa, y Jokin Alberdi ${ }^{74}$, profesor de Derecho Constitucional de la Universidad del País Vasco. Entre los cursos que ha organizado esta asociación señalamos el Master on line 2006-2007 en «Inmigración y Cooperación al Desarrollo en la Unión Europea».

\footnotetext{
Estudios Políticos y Constitucionales, Madrid, 2002; CAMPOS, A. (ed.): Ayuda, mercado y buen gobierno. Los lenguajes del desarrollo en África en el cambio de milenio, Icaria, Barcelona, 2005.

${ }_{74}$ PÉREZ DE ARMIÑO, Karlos: Diccionario de acción humanitaria y cooperación al desarrollo, Icaria y Hegoa, Barcelona-Bilbao, 2008; y Guía de rehabilitación posbélica: el proceso de Mozambique y la contribución de las ONG, Hegoa, Bilbao, 1997; BIDAURRATZAGA AURRE, Eduardo y SUTCLIFFE, Robert B.: La integración económica regional como estrategia de desarrollo en el África Austral, Universidad del País Vasco, Bilbao, 2002; ALBERDI BIDAGUREN, Jokin: La incidencia de la justicia comunitaria en las relaciones entre sociedad y Estado: el caso surafricano (1990-2000), Universidad del País Vasco, Bilbao, 2003.
} 


\subsection{Granada}

Encabezado por la profesora Soledad Vieite $z^{75}$, profesora de antropología, que habitualmente aborda temáticas relacionadas con el género y migraciones. Resaltamos entre los cursos organizados dentro de la Universidad de Granada el Máster Universitario en Desarrollo y Cooperación, por el Centro de Iniciativas de Cooperación al Desarrollo (CICODE), y el doctorado «Globalización, multiculturalismo y exclusión social: Desarrollo. Políticas sociales y trabajo social. Migraciones», durante el bienio 2005-2007.

\subsection{Alicante}

Liderado por Mercedes Jabardo, profesora de Antropología de la Universidad Miguel Hernández de Elche, que ha trabajado líneas investigadoras sobre diáspora y género, y Yolanda Aixelà Cabré ${ }^{76}$, profesora de Antropología Social en la Universidad de Alicante, que ha sobresalido en investigaciones sobre género.

\subsection{León}

Bajo el impulso de la profesora de la profesora Marta Sofía López Rodríguez, del Departamento de Filología Moderna de la Universidad de León y especialista en literatura africana se han organizado las Jornadas de Estudios Africanos desde el año $2000^{77}$.

\subsection{Salamanca}

Esta universidad cuenta con la impronta y trabajos de José Luis Cortés López, que es un gran conocedor de la Historia Africana y del Arte Africano. También queremos destacar los sucesivos congresos internacionales sobre la familia en África y la diáspora africana, coordinados por la profesora del Departamento de Filología Inglesa, Olga Barrios ${ }^{78}$.

75 VIEITEZ CERDEÑO, María Soledad: «Retos y estrategias del movimiento de mujeres mozambiqueñas: apuntes de una revolución de género contemporánea», en Mujeres de un solo mundo: globalización y multiculturalismo, Universidad de Granada. Granada, 2002, pp. 211-248.

76 JABARDO VELASCO, Mercedes: Senegaleses en España: conexiones entre origen y destino, Ministerio de Trabajo y Asuntos Sociales, Subdirección General de Información Administrativa y Publicaciones, Madrid, 2006; OKO GIEBELS, Machyta y AIXELÀ CABRÉ, Yolanda: Arte y Antropología: Una aproximación a la Guinea Ecuatorial Contemporánea, Ceiba ediciones, Vic, 2008.

77 LÓPEZ RODRÍGUEZ, Marta Sofía (ed.): I Jornadas de Estudios Africanos, Universidad de León, León, 2001.

${ }^{78}$ CORTÉS LÓPEZ, José Luis: Introducción a la Historia de África Negra, Espasa-Calpe, Madrid, 1984; y Esclavo y colono (introducción y sociología de los negroafricanos en la América española del si- 


\subsection{Canarias}

En la Universidad de Las Palmas de Gran Canaria existe un Master en Cooperación Internacional para el Desarrollo y un Centro Universitario de Cooperación Internacional para el Desarrollo. La Asociación Canarias de Estudios de la Globalización ha impulsado diversos cursos y seminarios dedicados a la temática africana en los últimos años. Entre sus miembros algunos profesores universitarios se han especializado en este continente como Lourdes Urbaneja, trabajando temas de cooperación desde la perspectiva de la Sociología. Conjuntamente con la Casa Museo León y Castillo se celebra el curso Historia de África: La Historia OIvidada. Identidades Culturales de África, coordinado por los profesores Juan Manuel y Germán Santana Pérez, que además han desarrollado temas relacionados con la Historia de África, sobre todo en el periodo de la esclavitud atlántica, y han impulsado la formación de un Grupo de Estudios Africanos en esta universi$\operatorname{dad}^{79}$.

En la Universidad de La Laguna existe un Centro de Estudios Africanos, que preside en la actualidad José S. Gómez Soliño, que ha desplegado su actividad dentro del Departamento de Filología. Sus componentes están detrás de la realización de varios cursos y seminarios dedicados a temas africanos en los últimos años.

\subsection{Otros centros}

Algunos de los africanistas españoles de las últimas décadas han realizado su labor fundamental en centros y universidades extranjeras. Un ejemplo es el antropólogo catalán Lluis Mallart ${ }^{80}$ que trabajó durante veinticinco años en la Universidad París X, en donde fundó el Fondo Lluis Mallart Guimerá en la biblioteca Eric de Dampierre. Un representante más reciente de esta corriente sería Carlos Oya, formado en Madrid y miembro del Centre of African Studies en la School of Oriental and African Studies (SOAS), en la Universidad de Londres, que ha venido investigando principalmente sobre temas de política económica africana. Ramón Sarró, formado en Barcelona, profesor sucesivamente en el University London College, en el SOAS y, hoy en día, en el Instituto de Ciências Sociais de Lisboa; sus trabajos

glo XVI), Universidad de Salamanca, Salamanca, 2004; BARRIOS HERRERO, Olga y SMITH FOSTER, Frances (eds.): Family in Africa and the African Diaspora: A Multidisciplinary Approach / La Familia en África y la diáspora africana: Un estudio multidisciplinar, Ediciones Almar, Salamanca, 2004.

79 URBANEJA CLERCH, Lourdes: La Comunidad Autónoma de Canarias y la cooperación para el desarrollo, Universidad de Las Palmas de Gran Canaria, Las Palmas de Gran Canaria, 2006; SANTANA PÉREZ, Germán y SANTANA PÉREZ, Juan Manuel: La puerta afortunada. Canarias en las relaciones hispano-africanas de los siglos XVII y XVIII, Los Libros de la Catarata, Cabildo de Gran Canaria, Cabildo de Lanzarote, Madrid, 2002.

80 MALLART GUIMERÁ, Lluis: Soy hijo de los evuzok: la vida de un antropólogo en el Camerún, Ariel, 1996; y La Forêt de nos ancêtres. Le système médical des evuzok du Camerún, Musée Royal de l'Afrique Centrale, Tevuren, 2003. 
versan sobre antropología y religión. Y Gustau Nerín ${ }^{81}$, formado en Barcelona como antropólogo, es hoy profesor en la Universidad Nacional de Guinea Ecuatorial (UNGE). Por otro lado, también debemos mencionar a africanistas africanos, que han realizado gran parte de su formación y elaboración de trabajos de investigación dentro de las fronteras españolas. En este grupo debemos encuadrar a literatos e historiadores tan reputados como los ecuatoguineanos Donato NdongoBidyogo y Justo Bolekia Boleká82.

Además de los centros que acabamos de mencionar, en numerosas universidades españolas se cuentan con Planes de Estudio que recogen varias asignaturas dedicadas a la Historia de África o a la temática africana, desde la Prehistoria hasta la actualidad.

En 1991 se celebró en Madrid el I Congreso de Estudios Africanos en el Mundo Ibérico, que ha tenido continuidad y se ha venido celebrando en diversas localidades de España y Portugal, y en el que han participado los principales africanistas de nuestro país. Hay que destacar la formación de la red de investigación ARDA-RIDA que conecta a los principales centros de investigación de nuestro país y también de Portugal. Internet ha contribuido también a la difusión de estos trabajos a través de páginas como Africainfomarket, Afrolnews y otras. También está suponiendo un hito en el apoyo a los estudios españoles en el África subsahariana la creación en 2006 de Casa África, con sede en Las Palmas de Gran Canaria, y que está llamada a desplegar una gran cantidad de actos culturales y actuar como institución de encuentro entre los diferentes africanistas españoles. Debemos destacar que en estos últimos años se constata una incorporación mayor de estudios africanistas protagonizados por mujeres, que aunque estaban presentes con anterioridad actuaban, por lo general de forma aislada y eran casi inexistentes antes del final de la dictadura.

El mismo cine español cuenta con trabajos insuficientes pero interesantes dedicados al África subsahariana, aunque centrados en Guinea Ecuatorial, como por ejemplo en la película Lejos de África, bajo la dirección de Cecilia Bartolomé o En el mundo a cada rato, en la que en una de sus historias «La vida efímera», dirigida por Pere Joan Ventura se desarrolla en la ex colonia, o documentales como el reciente Memoria Negra, dirigido por Xavier Montanyá. Dos festivales destacan en el panorama español por su contribución a un mayor interés cinematográfico desde España por el vecino continente: el Festival de Tarifa y la Mostra de cine de Barcelona.

81 SARRÓ, Ramón: Surviving Iconoclasm: Religious and Political Transformation on the Upper Guinea Coast, Edinburgh University Press, Edimburgo, 2006; OYA GÓMEZ, Carlos: «Privatizaciones en el África subsahariana", en Claves de la economía mundial, Instituto Español de Comercio Exterior (ICEX), 2006, pp. 420-426; NERÍN, Gustau: Guinea Ecuatorial, historia en blanco y negro. Hombres blancos y mujeres negras en Guinea Ecuatorial (1843-1968), Ediciones Península, Barcelona, 1998.

82 CASTRO, Mariano de y NDONGO, Donato: España en Guinea. Construcción del desencuentro: 1778-1968, Sequitur, Toledo, 1998; BOLEKIA BOLEKÁ, Justo: Aproximación a la historia de Guinea Ecuatorial, Amarú Ediciones, Salamanca, 2003. 
A esto habría que sumar las continuas exposiciones de muy diverso tipo que en los últimos años tienen como objeto el África subsahariana. También hay que recordar las muestras permanentes de obras de arte y antropología africana en Madrid, Barcelona y Valladolid.

\section{A MODO DE CONCLUSIÓN}

A lo largo de estas páginas hemos intentado esbozar las principales líneas de los estudios españoles sobre el África subsahariana. A través de ellas hemos podido comprobar cómo estas investigaciones se han ido ajustando y evolucionando a las distintas realidades cronológicas del espacio histórico. En ellas, la influencia sobre esta labor era casi siempre española más que africana, es decir, la orientación de los estudios tenía que ver más con lo que estaba ocurriendo en España y no tanto con lo que sucedía en África. Con todo, las tendencias de ellos poseían unas raíces diferentes a los trabajos que se realizaban sobre Europa y América, y que tenían que ver con los intereses hispanos en esta área.

A pesar de su existencia con anterioridad, el contacto directo con el mundo africano marcó de forma determinante la producción de los estudios africanistas españoles. En este sentido, los trabajos realizados por andalusíes fueron un buen ejemplo de ello. La expansión ultramarina primero y la fase de imperialismo en Guinea Ecuatorial, después, justificaron la mayor parte de las temáticas entre el siglo $X V$ y el $X X$.

Finalmente, durante el siglo XX, y en particular durante la dictadura franquista, el africanismo español, muy activo tanto en personalidades como en trabajos contó, sin embargo, con la rémora de la orientación política imperante, que lo limitó al área de sus colonias (tanto en los procesos de colonización como de descolonización) y lo alejó de las tendencias más modernizantes que se estaban poniendo en práctica en el resto de Occidente. Por último, tras la llegada de la democracia se ha observado una clara tendencia de puesta al día y de diversificación de los estudios, así como de los trabajos interdisciplinares. A pesar de la formación de nuevos centros e instituciones, y del gran salto cualitativo, todavía se está aún lejos de alcanzar los niveles de otros países, fundamentalmente en volumen de estudios y en inversión por parte de las autoridades estatales. 